\title{
Political Parties' Preferences about the Volume of Social Spending and its Distribution between Programs and Age Groups: a Comparative Study of France, Spain and the UK
}

\author{
Cristina Ares ${ }^{1}$, Antón Losada ${ }^{2}$
}

Recibido: 5/03/2020 / Aceptado: 03/06/2020

\begin{abstract}
The transformation of the Welfare State is not a standardized response to globalization or a by-product of European Union policies, but rather 'what parties make of it' (Burgoon, 2006). Different welfare regimes and welfare cultures contribute to the maintenance of diverse national responses to global and regional integration in terms of their public welfare systems, but there are also meso-level variables, such as parties' ideologies, that may have an impact on the volume and distribution of welfare expenditure. This article presents a new scheme and procedure to code party manifesto statements in favor of social spending and retrenchment; it applies them in Britain, France and Spain in order to show the possibilities of the new data. The preliminary results indicate that ideologies are linked to parties' preferences regarding the distribution of social spending between programs, the emphasis on different age groups as beneficiaries of welfare expenditure, and the rationale for social cuts.
\end{abstract}

Keywords: Social spending; social retrenchment; population aging; political parties; Manifesto Project.

Preferencias de los partidos políticos acerca del volumen de gasto social y su distribución entre programas y grupos etarios: un estudio comparado de España, Francia y el Reino Unido

Resumen. La transformación del Estado de bienestar no es una respuesta estandarizada a la globalización o un producto secundario de las políticas de la Unión Europea, sino "lo que los partidos consiguen" (Burgoon, 2006). Los diferentes regímenes y culturas de bienestar contribuyen al mantenimiento de respuestas nacionales diferenciadas a la integración global y regional en términos de sus sistemas públicos de bienestar. Pero variables de nivel meso, como la ideología de los partidos, pueden asimismo tener impacto no solo en el volumen total de gasto en políticas de bienestar sino también en su distribución entre programas y grupos de beneficiarios. Este artículo presenta un nuevo esquema de clasificación y procedimiento para obtener datos comparables sobre las preferencias de los partidos parlamentarios en materia de gasto social. Se aplica en tres elecciones generales de España, Francia y el Reino Unido para mostrar sus posibilidades de empleo. En los partidos parlamentarios resultantes de estos comicios, la ideología está relacionada con las preferencias sobre la distribución del gasto social entre programas y beneficiarios, incluida la respuesta al envejecimiento de la población, así como la racionalidad de los recortes en la financiación del sistema público de bienestar.

Palabras clave: Gasto social; recortes sociales; envejecimiento de la población; partidos políticos; proyecto Manifesto.

Sumario. 1. Introduction. 2. Method. 2.1. The Manifesto Dataset as the starting point. 2.2. 20-item classification on social spending and retrenchment. 2.3. Procedure to code programmatic statements on welfare expenditure. 3. Why study France, Spain, and the UK? 4. Analysis. 4.1. Parties' preferences on the distribution of social spending between programs. 4.2. Emphasis on age groups. 4.3. Rationales for social retrenchment. 5. Conclusions.

Cómo citar: Ares, C.; Losada, A. (2020): Political Parties' Preferences about the Volume of Social Spending and its Distribution between Programs and Age Groups: a Comparative Study of France, Spain and the UK, en Cuadernos de Gobierno y Administración Pública 7-2, 85-98.

'Understanding the operation of electoral democracy is constitutive in order to account for variance over time and across space in policies and quality of life outcomes delivered by postindustrial democracies' (Beramendi, Häusermann, Kitschelt and Kriesi, 2015: 59)

'We have arguably exaggerated the influence of globalization and technology while paying too little attention to changes induced by the new demography. This is particularly the case for social inequalities' (Esping-Andersen, 2009: 168)

\footnotetext{
Universidad de Santiago de Compostela. cristina.ares@usc.es

2 Universidad de Santiago de Compostela. antonio.losada@usc.es
} 


\section{Introduction}

Starting in the 1990s, research on European social policies has looked for a hypothetical convergence on national welfare expenditures. It examined the impact of European Union (EU) constraints: firstly, the so-called 'convergence criteria' introduced as requirements to gain access to the Eurozone, and later on, during the Great Recession, the conditions imposed to receive financial support in countries like Greece, Ireland and Portugal (Costamagna, 2013; Darvas and Tschekassin, 2015; Degryse, Jepsen and Pochet, 2013; De la Porte and Heins, 2015; Vaughan-Whitehead, 2015). It also considered whether the open method of coordination (OMC) applied at EU level for certain domains that remained under national control was used to induce domestic budgetary cuts or, far from fostering social retrenchment, it served to help laggards to extend the social protection of their citizens (De la Porte and Pochet, 2012; Natali, 2009). ${ }^{3}$ In one direction or another, progressive convergence on social spending within the EU was expected.

Nevertheless, differences in social spending across European countries persist. In 2015, the median expenditure on social protection in the EU-15 (Austria, Belgium, Denmark, Finland, France, Germany, Greece, Ireland, Italy, Luxembourg, Netherlands, Portugal, Spain and Sweden) was $28.41 \%$ of the GDP. France remained the leader (33.9\% of the GDP), while Ireland was the laggard (20.6\% of the GDP). ${ }^{4}$

Domestic political factors play a role in maintaining this variation (Beramendi et al., 2015; Huber and Stephens, 2015). At the macro level of the countries, varieties of capitalism (Hall and Soskice, 2001), types of welfare regime (Esping-Andersen, 1990; 1999) or welfare cultures (Pfau-Effinger, 2005) came into play. In addition, at the macro level of the party systems and at the meso level of the parties, partisanship is a factor. Thus, an improved measurement of parties' preferences on social spending was needed to widen the explanation of persisting diverse national priorities regarding social spending beyond the impact of welfare institutions and welfare cultures.

Expenditure on social protection is worthy of study because it is one of the most important attributes in the definition of the Welfare State. This is a European phenomenon that can be defined by a minimum social investment of $20 \%$ of the GDP, which represents around half of national public spending (Moreno, 2016). The Welfare State more broadly applies the values of equality, freedom, and solidarity across Europe by protecting citizens from social risks and offering them an array of social services unrelated to their socioeconomic conditions (Briggs, 2000).

The 'open method of coordination' (OMC) is a mode of EU policymaking that falls between intergovernmental cooperation and the classical Community method; the latter gives autonomy to supranational institutions, such as the European Commission or the Court of Justice, while under OMC, EU Member States merely define common objectives and share information on policy instruments and results. In other words, the $\mathrm{OMC}$ is a terrain of soft law and policy learning.

4 Data from Eurostat corresponding to 2015, except from Ireland, which correspond to 2014. A short description of the 'expenditure on social protection': social benefits, administrative costs, and miscellaneous expenditures by social protection schemes; it is calculated in terms of current prices.
Consequently, this article introduces a new scheme and procedure to measure parties' preferences on social retrenchment and the distribution of social spending between programs and groups of beneficiaries. It presents a classification that contains 20 items to categorize the beneficiaries and programs prioritized by each party, along with the rationale for their critiques of social expenditure.

Age groups are considered relevant because a major priority at the inception of the European Welfare States was covering old age as a risk. This notwithstanding, from the mid-1990s on, the idea that there should not be redistribution between the age cohorts to the detriment of the younger generations spread from the United States, and the Great Recession raised new questions about how the European intergenerational contract can be sustained (author; Bristow, 2015; Esping-Andersen, 2009; Goerres, 2009; Häusermann, 2010; Kohli, 2015; Lynch, 2006; 2015). Today the impact of population aging on social policies is a salient topic of public debate in many European countries.

Accordingly, four items concerning age groups as beneficiaries of social spending were introduced in the new classification to capture the extent to which parties take into account the ongoing population change, and whether they prioritize some age groups over others as beneficiaries of social spending.

To show the possibilities of the new data, the 20 -item scheme is applied for the first time in three general elections [Britain (2015), France (2017) and Spain (2016)]. The manifestos of the 13 main state-wide parliamentary parties in these countries and legislative periods were recoded. The parties examined, with their political family in parentheses, are: Democratic Mouvement (conservative), Indomitable France (left), National Front (nationalist), Republic Onwards! (liberal), Socialist Party (social democratic), The Republicans (conservative); Citizens (liberal), Popular Party (conservative), Spanish Socialist Workers' Party (social democratic), United We Can (left); Conservative Party (conservative), Liberal Democrats (liberal), and Labour Party (social democratic). The party family is given in the Manifesto Dataset. ${ }^{5}$ The expectation of this preliminary analysis is that ideology is linked to parties' preferences on social spending concerning beneficiaries and programs as well as the rational for social retrenchment.

\section{Method}

\subsection{The Manifesto Dataset as the starting point}

The data processed were generated through the analysis of the political manifestos. The empirical points of departure are the Manifesto Dataset and the Manifesto Corpus (https://manifestoproject.wzb.eu).

The variable party family is constant in the Manifesto Dataset. It is assigned when a party is added to the database. The options are as follows: $10 \mathrm{ECO}$ - ecological parties, $20 \mathrm{LEFT}$ - socialist and other left parties, 30 SOC - social democratic parties, 40 LIB - liberal parties, $50 \mathrm{CHR}$ - christian democratic parties, $60 \mathrm{CON}$ - conservative parties, 70 NAT - nationalist parties, 80 AGR - agrarian parties, 90 ETH - ethnic and regional parties, 95 SIP - special issue parties, 98 DIV - electoral alliances of diverse origin without dominant party. 
The Manifesto Dataset contains numerical data for each program, derived by content-analyses of all its (quasi-) sentences. Quasi-sentences are parts of very long sentences which combine more than one argument. The entries in this dataset are specified positions such as 'Welfare State Expansion' or 'Welfare State Limitation' given as a percentage of (quasi-) sentences out of the total number of all (quasi-) sentences in the program.

The following are the definitions of the four variables contained in the Manifesto Project's standard scheme considered:

"Welfare State Expansion", 504. Favorable mentions of the need to introduce, maintain or expand any public social service or social security scheme. This includes, for example, government funding of health care, childcare, elder care and pensions, as well as social housing. This category excludes education.

'Welfare State Limitation', 505. Limiting state expenditures on social services or social security. Favorable mentions of the social subsidiary principle (i.e., private care over state care).

'Education Expansion', 506. The need to expand and/ or improve educational provisions at all levels. This excludes technical training, which is coded under 411. 'Education Limitation', 507. Limiting state expenditure on education. This may include the introduction or expansion of student fees at all educational levels and the increase in the number of private schools.

The scheme of the Manifesto Project also contains a variable that captures pronouncements in favor of equality; this is referred to as 'Equality Positive' (503). This category is used by the Project to calculate the parties' preferences on the Welfare State. However, it is not employed in this research, which is focused on spending, because it has no direct budgetary implications.

The variables described are used to calculate the position of the national parliaments in each legislature on the volume of social spending and its emphasis on social retrenchment. Both the position on social spending and the emphasis on social retrenchment are measured for all welfare policies, including education. For the calculations, initially, the punctuation of each party that was represented in the parliament in each legislature is obtained. Next, a measure for the national party system is derived by weighting the preference of each party with their strengths in terms of seats in parliament. The formulas are as follows: position on social spending $[(504+506)-(505+507)]$, in a theoretical range between +100 and -100 ; emphasis on social retrenchment $(505+507)$, in a theoretical range between +100 and $0 .{ }^{6}$

Furthermore, thanks to the Manifesto Corpus (Merz et al., 2016), to broaden the comparative analysis, this contribution moves beyond the former overall preferences on social investment and retrenchment by shed-

\footnotetext{
Position on social spending +100 would imply that the whole party manifesto would be devoted to more social spending, while a punctuation of -100 would mean that the entire programmatic offer would be composed of statements on social retrenchment. Emphasis on social retrenchment between +100 and 0 gives the percentage of mentions to social cuts out of the total number of units of analysis.
}

ding light on aspects that remained masked behind similar party positions in favor of more social spending.

The Manifesto Corpus is a systematic replication of original program texts in machine-readable format. To each (quasi-) sentence text, it adds the content-analytical numeric, e.g. the position given in the Manifesto Datasets in an aggregated version for each program, as well as meta data for countries, elections, and parties. The Corpus currently covers more than 2250 machine-readable programs from more than 50 different countries in more than 35 languages. It offers more than 925,000 coded quasi-sentences. The party and election dates can be used to link the Corpus information to the Manifesto Dataset.

The only well-known precedents of using the Manifesto Corpus to deliver more detailed party preferences on welfare policies are the works by Horn and van Kersbergen (2015) and Horn, Kevins, Jensen and van Kersbergen (2017), who recoded quasi-sentences on equality and welfare of German and United States electoral programs. The Manifesto Project's category 504 ('Welfare State Expansion') was re-categorized under five subcategories: status quo + (praise of the status quo/what has been achieved), status quo - (criticisms of the status quo, pointing to problems), future + (calls for expansion of programs in the future), future - (negative expectations that make adaption necessary), miscoded (not related to the description of item 504) (Horn et al., 2017: 416).

The former is a valuable output, but it does not capture the distribution of the parties' preferences on social spending between the beneficiaries and programs, which are aspects of the electoral offer that should seemingly have policy effects on the allocation of social spending and retrenchment during a parliamentary period.

\subsection{0-item classification on social spending and retrenchment}

In this article, the following 17 items were proposed and used to classify according to the beneficiaries and programs addressed the statements that suggest more social spending:

Age groups: children (and adolescents), 10; young people, 20; working-age people, 30; older-age adults, 40

Other beneficiaries: disabled people, 1; emigrants, 2; families, 3; people at risk of poverty or social exclusion, 4

Programs: education, 5; emergency services, 6; employment, 7; gender violence, 8 ; health, 9; housing, 10; pensions, 11; social services, 12

General statements (and others), 13

The 4 categories on age groups consider only general measures offered to the group. If they frequently occur, it means that the party is aware of the importance of these social divisions, and it could be prioritizing one or more age groups. To measure all statements that would benefit a particular age group, some of the other 13 categories on welfare programs and beneficiaries must be aggregated in the analysis.

See in Table 1 some examples for re-categorization of the items 'Welfare State Expansion' and 'Education Expansion'. 
Table 1. Examples for re-categorization of the items 'Welfare State Expansion' and 'Education Expansion'.

\begin{tabular}{|c|c|}
\hline Item, code & Example (Original language in parentheses) \\
\hline \multicolumn{2}{|l|}{ Age groups } \\
\hline Children (and adolescents), 10 & $\begin{array}{l}\text { 'We will prioritize early years intervention to give children and parents the best start in family } \\
\text { life, and restore the role of Sure Start centres and family hubs' (Labour Party, 2015) }\end{array}$ \\
\hline Young people, 20 & $\begin{array}{l}\text { To establish an autonomy benefit for young people aged } 18 \text { to } 25 \text { years, for three years } \\
\text { (Instaurer une allocation d'autonomie pour les jeunes de } 18 \text { à } 25 \text { ans, d'une duration de trois } \\
\text { ans) (Indomitable France, 2017) }\end{array}$ \\
\hline Working-age people, 30 & $\begin{array}{l}\text { A guaranteed salary complement to help low-income workers to make a decent salary (Un } \\
\text { complemento salarial garantizado para ayudar a los trabajadores con menores ingresos a que } \\
\text { tengan un sueldo digno) (Citizens, 2016) }\end{array}$ \\
\hline Older-age adults, 40 & $\begin{array}{l}\text { 'We will cap the amount you can be charged for your residential care - so you can have the } \\
\text { dignity and security you deserve in your old age' (Conservative Party, 2015) }\end{array}$ \\
\hline \multicolumn{2}{|l|}{ Other beneficiaries } \\
\hline Disabled people, 1 & $\begin{array}{l}\text { To impose access standards for the partially-sighted and the partially deaf (Imposer un } \\
\text { standard d'accessibilité pour les malvoyants et les malentendants) (National Front, 2017) }\end{array}$ \\
\hline Emigrants, 2 & $\begin{array}{l}\text { We will guarantee the European health insurance card to all Spanish citizens living abroad } \\
\text { (Garantizaremos tarjeta sanitaria europea a toda la ciudadania española en el exterior) } \\
\text { (United We Can, 2016) }\end{array}$ \\
\hline Families, 3 & $\begin{array}{l}\text { We take a commitment to implement measures for the social well-being of families (Nos } \\
\text { comprometemos a poner en marcha medidas por y para el bienestar social de las familias) } \\
\text { (Spanish Socialist Workers' Party, 2016) }\end{array}$ \\
\hline $\begin{array}{l}\text { People at risk of poverty or } \\
\text { social exclusion, } 4\end{array}$ & $\begin{array}{l}\text { Create a 'guarantee of dignity' by increasing the social minimum (no standard of living below } \\
\text { the poverty line) [Créer une 'garantie dignité en revalorisant les minima sociaux (aucun } \\
\text { niveau de vie en dessous du seuil de pauvreté)] (Indomitable France, 2017) }\end{array}$ \\
\hline \multicolumn{2}{|l|}{ Programs } \\
\hline Education, 5 & $\begin{array}{l}\text { 'A new School Leadership Institute will support headteachers and improve school leadership' } \\
\text { (Labour Party, 2015) }\end{array}$ \\
\hline Emergency services, 6 & $\begin{array}{l}\text { We will work for a modern emergency system that will be effective in preventing risks and } \\
\text { repairing damages (Trabajaremos por un Sistema de Emergencias moderno y eficaz en la } \\
\text { prevención de riesgos y la reparación de daños) (Popular Party, 2016) }\end{array}$ \\
\hline Employment, 7 & $\begin{array}{l}\text { We will extent the eligibility for unemployment insurance to employees who resign (Nous } \\
\text { ouvrirons les droits à l'assurance chômage aux salaries qui démissionnent) (Republic } \\
\text { Onwards!, 2017) }\end{array}$ \\
\hline Gender violence, 8 & $\begin{array}{l}\text { We will improve teleassistance and police and judicial coordination for the protection of } \\
\text { women victims of domestic violence (Mejoraremos la teleasistencia y la coordinación policial } \\
\text { y judicial en la protección de las mujeres maltratadas) (Popular Party, 2016) }\end{array}$ \\
\hline Health, 9 & $\begin{array}{l}\text { Guarantee everyone, independently from their gender orientation and marital status, the } \\
\text { access to assisted reproduction in the public health system (Garantizar el acceso de todas las } \\
\text { personas, con independencia de su orientación social y estado civil, a la reproducción asistida } \\
\text { dentro del sistema sanitario público) (Spanish Socialist Workers' Party, 2016) }\end{array}$ \\
\hline Housing, 10 & $\begin{array}{l}\text { We will reform the local tax law to exempt empty homes transferred by their owners to social } \\
\text { housing funds from paying the property tax (Modificaremos la Ley de Haciendas Locales para } \\
\text { que aquellas viviendas deshabitadas que sean cedidas por sus propietarios a fondos sociales } \\
\text { de vivienda no paguen IBI (Impuesto sobre los Bienes Inmuebles)) (Citizens, 2016) }\end{array}$ \\
\hline Pensions, 11 & $\begin{array}{l}\text { 'And when you retire we will continue to increase the Basic State Pension by at least } 2.5 \text { per } \\
\text { cent through the triple lock' (Conservative Party, 2015) }\end{array}$ \\
\hline Social services, 12 & $\begin{array}{l}\text { 'Raise the professional status and training of care home managers through statutory licensing' } \\
\text { (Liberal Democrats, 2015) }\end{array}$ \\
\hline $\begin{array}{l}\text { General statements (and } \\
\text { others), } 13\end{array}$ & $\begin{array}{l}\text { We must fix our Welfare State and adjust it to the 21st century society (Debemos recomponer } \\
\text { nuestro Estado del Bienestar y adecuarlo a la sociedad del siglo XXI) (Spanish Socialist } \\
\text { Workers' Party, 2016) }\end{array}$ \\
\hline
\end{tabular}


Moreover, the new scheme contains the following 3 items to measure the rationale for the critiques of social expenditure:

Macroeconomic, 100. Social spending is bad for the national economy; it reduces economic competitiveness or growth.

Mismanagement, 200. Social spending is ineffective; it does not achieve its goals in terms of reducing poverty or increasing equality.

Moral, 300. Social spending has negative effects on individual responsibility or social cohesion within families and communities.

See some examples for re-categorization of the items 'Welfare State Limitation' and 'Education Limitation' in Table 2 .

\subsection{Procedure to code programmatic statements on welfare expenditure}

The Excel files of the 'annotated programs' were used as a starting point for the recoding (Merz et al., 2016). These files contain the original text cut into units of analysis and the content analytical variable assigned to each unit of analysis by the Manifesto Project's coders. The unit of analysis is the quasi-sentence, which is a sentence of a part of a sentence that contains a sole argument. The 'annotated programs' can be downloaded from the website of the project (https://visuals.manifesto-project.wzb.eu/mpdb-shiny/cmp_dashboard_dataset/).

The unit of analysis, the quasi-sentence, was maintained to generate the new data on social spending. The re-coding was done in two steps: in the first step, the statements on 'Welfare State Expansion' (504), 'Welfare State Limitation' (505), 'Education Expansion' (506) and 'Education Limitation' (507) were identified in the 'annotated program' and saved in a new file; in the second step, the classification according to the 20 new items was implemented in this folder.
Sentences previously coded as 504 and 506 were re-classified according to beneficiaries and programs, and statements originally coded as 505 and 507 were re-categorized in relation to the type of critique of social spending they contained. Only one category was assigned to each unit. The most important information given in the statement was coded. Categories can always be aggregated afterwards in the analysis.

Finally, the percentage of units of analysis in favor of increasing social spending (504 plus 506) out of the total number of units coded as 'Welfare State Expansion' (504), 'Welfare State Limitation' (505), 'Education Expansion' (506) and 'Education Limitation' (507) is also provided in the new database. This was given the title Parties' Social Spending Profiles' dataset.

\section{Why study France, Spain, and the UK?}

Comparative institutionalism, essentially the varieties of capitalism approach described by Hall and Soskice (Hall and Soskice, 2001) and the Esping-Andersen regime typology (Esping-Andersen, 1990; 1999), was frequently applied to assess cross-country variation in social protection, not only at the inception of the Welfare States after World War II, but also over time (Ebbinghaus and Manow, 2001; Ebbinghaus, 2012; Hall and Soskice, 2001: 66).

On the basis of how firms resolve their coordination difficulties, Hall and Soskice defined two ideal types of political economies: 'liberal market economies' and 'coordinated market economies.' These are considered to be the extremes on a continuum, along which different countries could be placed. In liberal market economies, firms coordinate their actions mainly towards competitive market solutions, while in coordinated market economies, they are more dependent on non-market modes of coordination. From this perspective, cultural and institutional factors play a crucial role in explaining how firms deal with their coordination problems. As Hall and Soskice put it, "each economy displays specific capacities for coordination

Table 2. Examples for re-categorization of the items 'Welfare State Limitation' and 'Education Limitation'.

\begin{tabular}{|l|l|l|}
\hline \multicolumn{1}{|c|}{ Item, code } & \multicolumn{1}{|c|}{ Description } & \multicolumn{1}{c|}{ Example (Original language in parentheses) } \\
\hline $\begin{array}{l}\text { Macroeconomy, } \\
100\end{array}$ & $\begin{array}{l}\text { Social spending is bad for the country } \\
\text { economy; it reduces economic } \\
\text { competitiveness or growth. }\end{array}$ & $\begin{array}{l}\text { 'We will cap structural social security spending as part of each } \\
\text { spending review, so that it is properly planned and controlled' } \\
\text { (Labour Party, 2015) }\end{array}$ \\
\hline $\begin{array}{l}\text { Mismanagement, } \\
\text { Morality, }\end{array}$ & $\begin{array}{l}\text { Social spending is ineffective; it does } \\
\text { not achieve its goals in terms of reducing } \\
\text { poverty or increasing equality. }\end{array}$ & $\begin{array}{l}\text { The social security scheme for self-employed workers, that } \\
\text { is not working, will be removed (Supprimerons le Régime } \\
\text { Social des Indépendants (RSI) qui ne fonctionne pas) (The } \\
\text { Republicans, 2017) }\end{array}$ \\
\hline $\begin{array}{l}\text { Social spending has negative effects } \\
\text { on individual responsibility or } \\
\text { social cohesion within families and } \\
\text { communities. }\end{array}$ & $\begin{array}{l}\text { 'We will replace the Jobseeker's Allowance for 18-21 year- } \\
\text { olds with a Youth Allowance that will be time-limited to } \\
\text { six months, after which young people will have to take an } \\
\text { apprenticeship, a traineeship or do daily community work for } \\
\text { their benefits' (Conservative Party, 2015) }\end{array}$ \\
\hline
\end{tabular}


that will condition what its firms and governments do" (Hall and Soskice, 2001: 35).

It is worth noting how the 'varieties of capitalism approach' (or VoC) already calls into question the recurrent understanding of globalization as a process with a similar impact on firms and governments across countries. The VoC perspective expects widespread deregulation in liberal market economies, but limited changes in coordinated market economies. Indeed, it stresses that "because of comparative institutional advantage, nations often prosper, not by becoming more similar, but by building on their institutional differences" (Hall and Soskice, 2001: 60).

This is linked to the different scope and range of social policies in the various VoC. For instance, while more public investments in workers to foster their productivity and specialization, which implies a reduction in the firms' budgets devoted to training their own employees, is assumed in coordinated market economies, in liberal market economies neither the public sector nor directly the firms but the workers themselves are supposed to pay for their own training.

Esping-Andersen's welfare 'regimes' or 'worlds' is another extensively used comparative institutionalist perspective. The three regimes are: i) social-democratic, which can be found to varying extents in Denmark, Finland, the Netherlands, Norway and Sweden, ii) liberal (in the UK, only to a degree; mainly found in Australia, Canada, New Zealand and the United States), and iii) continental (Austria, Belgium, France, Germany, Italy, Portugal and Spain) (Arts and Gelissen, 2010; Castles and Obinger, 2008; Ferragina, Seeleib-Kaiser and Spreckelsen, 2015). Governments, markets and families are the main pillars, respectively, of each of the three worlds. Authors who cluster Southern European countries into a separate fourth welfare regime underline the further importance of family in this last group of Mediterranean countries (Ferrera, 1996; Leibfried, 1992), although it must be recognized that this is not a qualitative difference.

For Esping-Andersen, the main criterion to differentiate between welfare regimes is "the degree to which individuals, or families, can uphold a socially acceptable standard of living, independently of market participation" (Esping-Andersen, 1990: 37; 1999: 74); this is called the degree of decommodification. Diversity in social policies among the distinct welfare worlds also fosters dissimilar models of social stratification. When Esping-Andersen re-examined his typology in 1999, he gave more importance to families as one of the three pillars of well-being of each regime. He added that the 'incomplete revolution,' which during recent decades has been promoted by some skilled working women, is one of the main drivers of Welfare State renewal, with effects on markets, families, and governments (Esping-Andersen, 2002; 2009; 2015).

Pfau-Effinger proposed the 'welfare arrangement approach' to focus on the relationship between welfare state policies and cultures, where 'culture' means the complex of relevant 'ideas in a given society surrounding the welfare state and the way it is embedded in soci- ety', for example, the Western Germany conviction that home is the best place for children below the age of three (Pfau-Effinger, 2005: 4 and 12). Countries belonging to the same Esping-Andersen's type of regime may have different welfare cultures. It means that Welfare States are less coherent unities in cross-national comparisons than could be assumed.

France, Spain, and the UK were the countries selected for this preliminary analysis to include different types of market economies. France is a good case of a coordinated market economy and the UK is a good example of a liberal market economy. Spain, which falls somewhere in between, can nowadays be situated close to Britain on the continuum, due to the extensive privatizations and labor market deregulations implemented. In 2016 (the year with the last available data from the OCDE), the UK (33.2\% of the GDP) and Spain (33.5\% of the GDP) had nearly the same percentage of total tax revenues. This situated them closer to the United States $(26.0 \%$ of the GDP) than France (45.3\% of the GDP), Italy (42.9\% of the GDP) or Sweden and Finland (both $44.1 \%$ of the GDP). In terms of social spending, in the same year, the Spanish figure (24.6\% of the GDP) was also more similar to British expenditure (21.5\% of the GDP) than that of the French (31.5\% of the GDP). ${ }^{7}$

\section{Analysis}

To start with, regarding the wide-ranging preferences on social spending, at the macro level of the party systems, across the EU-15, a trend appeared towards greater support for social spending during the toughest years of the Great Recession. This included Spain - where, indeed, the promotion of social investment has grown consistently since the late 1990s-, and the UK, but not France, where it decreased by $41.92 \%$ since 2007 . At the macro level, in the three elections covered in this analysis, variations in scores among the countries range from 11.29 (out of 100) for the support for social spending in France and 16.2 (out of 100) in Spain. The French 2017 general election is a deviant case. This is in connection with the decrease in electoral support for the Socialist Party and the emergence of the Republic Onwards!, given that this latter party was less in favor of the expansion of social spending than not only its liberal counterparts, but also the British and Spanish conservative parties.

At the meso level of the parties, diversity within countries was low, except in France, where the differences between parliamentary parties were intense in 2017. All these measures can be consulted in the appendix, in Table A1.

In moving forward, thanks to the new Parties' Social Spending Profiles' dataset, three aspects will be additionally compared in this article: the relative attention paid to the various welfare programs, the emphasis on age groups, and the rationale for social retrenchment when it is mentioned in the party manifesto.

Total public social spending includes all financial flows from the public sector for social purposes. 
Graph 1. Parliamentary position on social spending.

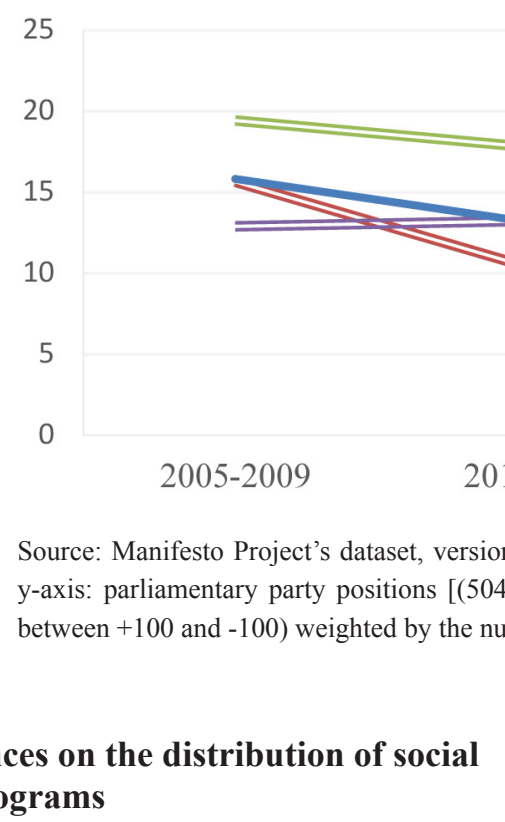

\subsection{Parties' preferences on
spending between programs}

At first glance, the concentration or dispersion of party statements in favor of social spending in certain programs, while at the same time avoiding others, reveals meaningful differences that were previously masked by the general measure of party support for the expansion of social spending.

To start with education, conservative and liberal parties systematically place more relative emphasis on this program than left-wing, and in particular, social democratic parties. More than 4 out of 10 of the conservative and liberal statements in favor of expanding social spending deal with education, while in the case of the social democratic parties, these represent only 2 out of 10. Social democratic parties offer proposals on education as well; however, conservative and liberal parties do not give the same importance to other social programs.

The limited number of relevant social programs from the point of view of liberal and conservative parties is noticeable when summing up their statements on educa- tion and health. It is worth pointing out that while social democratic parties do not pay less attention to health expenditures than liberal and conservative parties neither, social democrats also support more social spending beyond education and health.

These 'other' relevant welfare programs from the point of view of social democratic parties vary from country to country.

The new 20 categories capture this diversity for all parties and countries in a straightforward manner too. See graphs 3 to 5 .

In these three elections, social democratic parties consistently offered measures to aid disabled people. In the UK, neither the Conservative Party nor the Liberal Democrats did this. In Spain, all manifestos contained references to the disabled, which were more important for the United We Can and Citizens parties than for the Popular Party and the Socialist Workers' Party. In France, all parties made proposals concerning expenditure for disabled people, with remarkable variation in emphasis among them. The most focused on this social group were the Socialist Party, The Republicans and the National Front.

Graph 2. Emphasis on education and health.

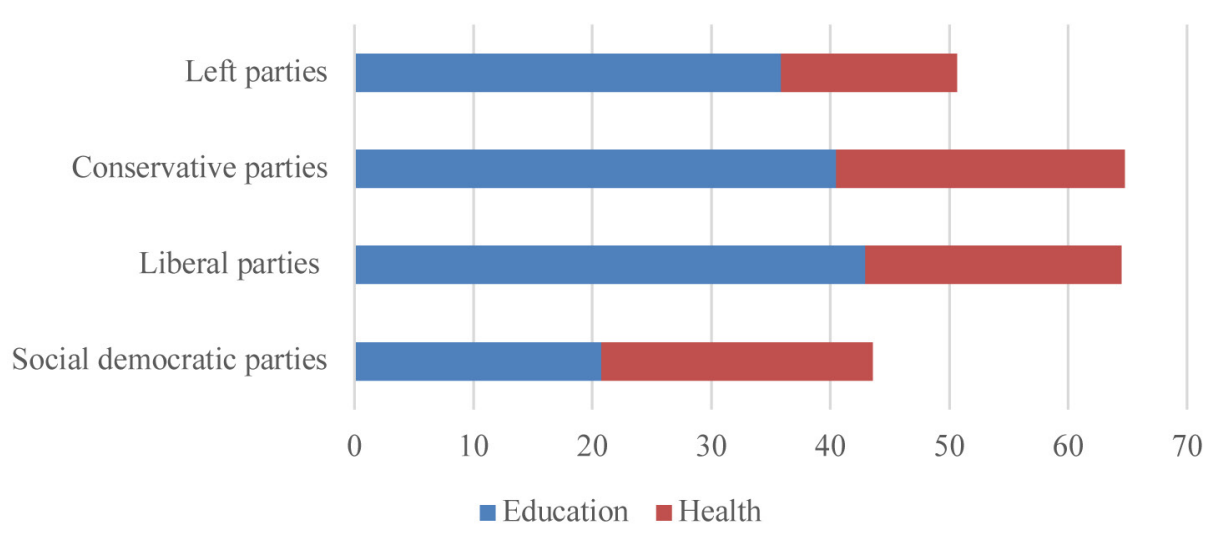

Source: Parties' Social Spending Profiles' dataset, version 2018. Percentage of statements dealing with education and health out of the total welfare offer. 
Conservative parties paid more attention to pensions than social democratic parties in the UK and France, but not in Spain. In Britain and Spain, liberal parties also gave importance to social services.

In the UK, the prioritized programs were limited to basically health, education, pensions and social services, while in Spain many more categories were present, in terms of both beneficiaries and programs. These variables were, for instance, "people at risk of poverty or social exclusion' (emphasized by United We Can), 'families' (prioritized by the Popular Party), 'housing' (emphasized by both the Socialist Workers' Party and United We Can) and 'employment' (prioritized by the Socialist Workers' Party).

In France, 'people at risk of poverty or social exclusion' were addressed by the newcomers Republic Onwards! and, in particular, by Indomitable France, while 'housing' was identified as a concern for the National Front and the Democratic Mouvement; 'employment' was addressed by Republic Onwards!, Indomitable France and especially the Socialist Party, for whom 3 out of 10 welfare statements dealt with jobs.

\subsection{Emphasis on age groups}

Concerning the awareness about the population change, first, the evidence from these three elections reveals that social democratic parties showed more concern for age groups.

The best case is the Labour Party, which emphasized both children and older-age adults; to a lesser extent, the Spanish Socialist Workers' Party gave priority to children, and the French Socialist Party, to a greater degree, concentrated on older-age adults.

It is worth noting that in Britain, the three main statewide parties made proposals for all or some of the age groups, while in France, apart from the Socialist Party's marked focus on older-age adults, this only occurred with The Republicans, who emphasized both children and young people. In Spain, the Socialist Workers' Party paid particular attention to children, whereas the Popular Party did so to older-age adults; Citizens showed interest not only in children, but also in working-age people, and United We Can assigned the same importance to all four age groups.

Graph 3. Everything but education and health. Percentage of statements dealing with other beneficiaries and programs out of the whole offer on social spending in Britain (2015).

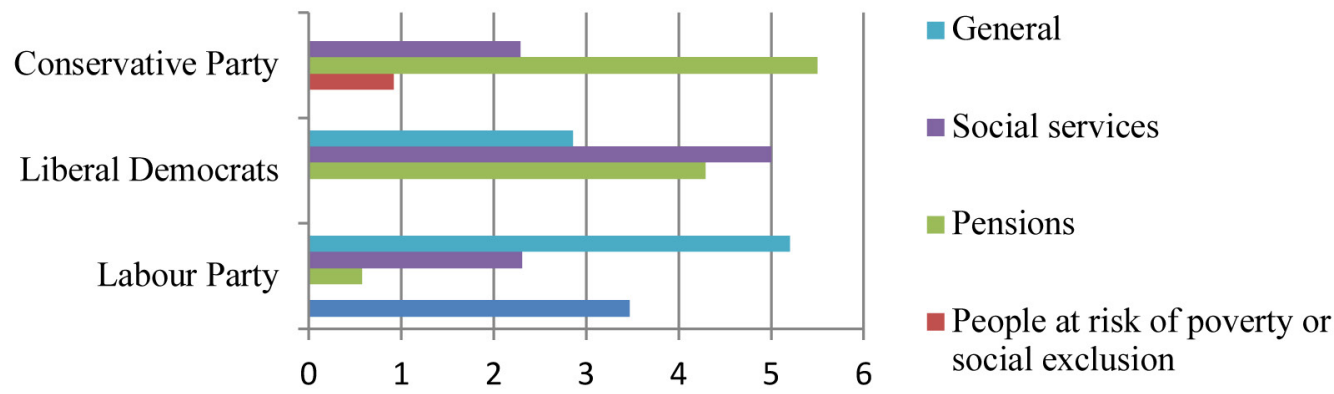

Source: Parties' Social Spending Profiles' dataset, version 2018.

Graph 4. Everything but education and health. Percentage of statements dealing with other beneficiaries and programs out of the whole offer on social spending in Spain (2016).

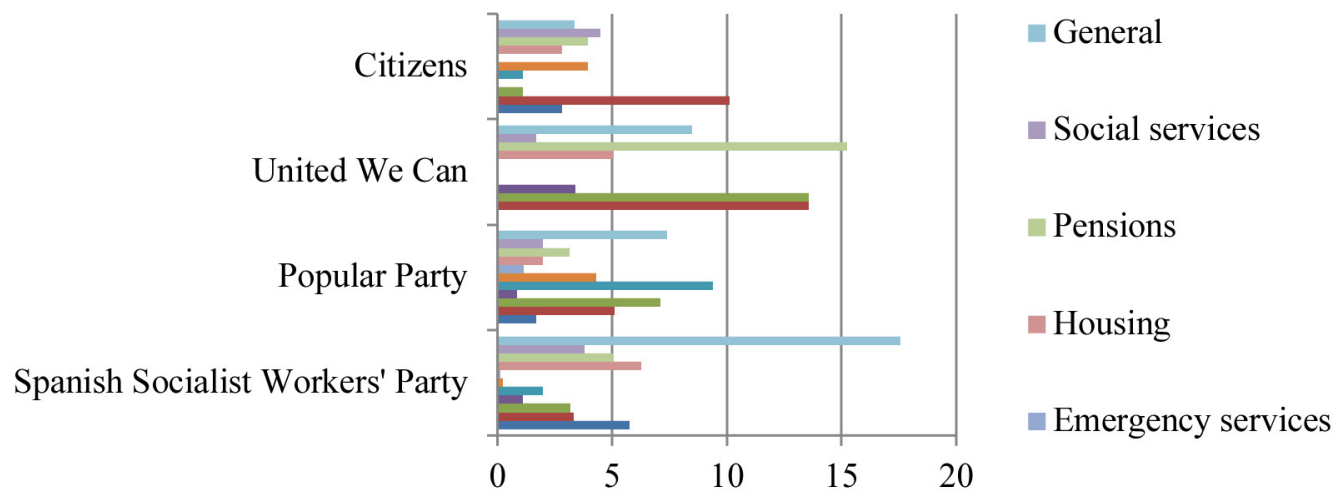


Graph 5. Everything but education and health. Percentage of statements dealing with other beneficiaries and programs out of the whole offer on social spending in France (2017).

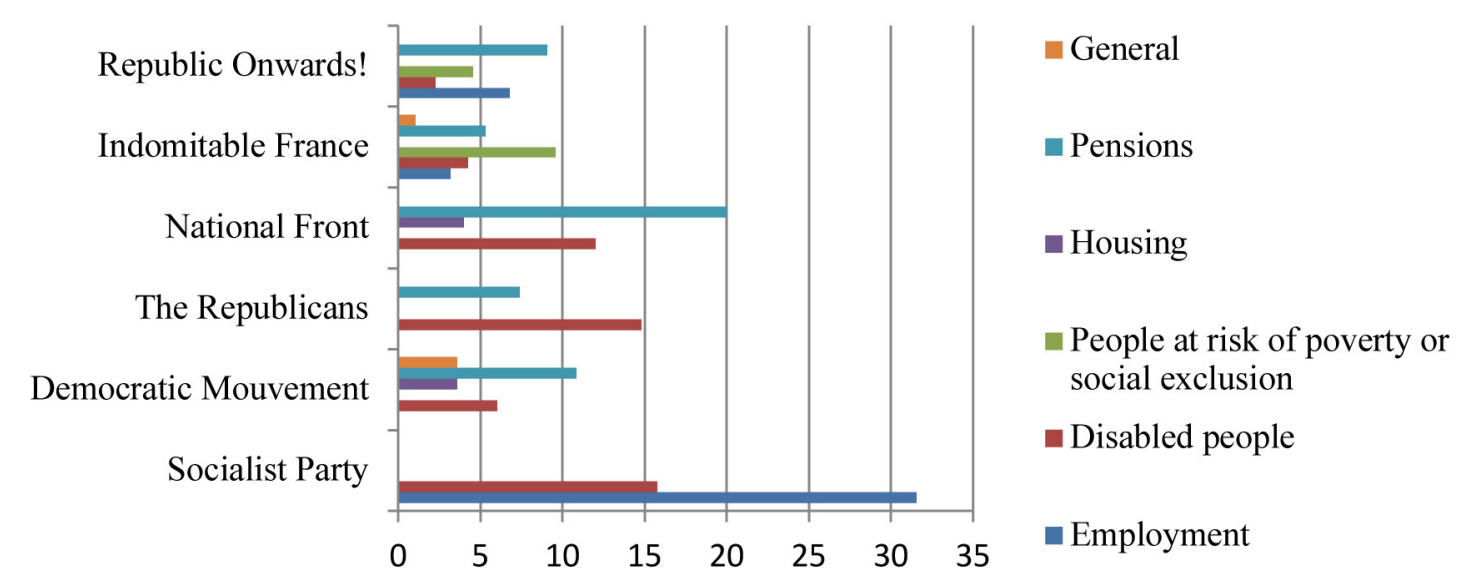

Source: Parties' Social Spending Profiles' dataset, version 2018.

Graph 6. Emphasis on age groups.

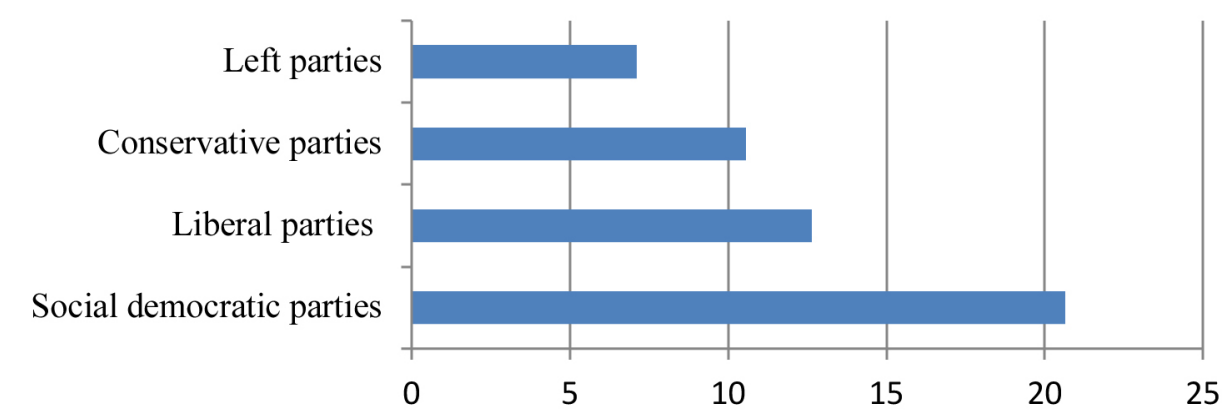

Source: Parties' Social Spending Profiles' dataset, version 2018. The emphasis on the 4 categories on age groups, on the $\mathrm{x}$-axis, measures the importance of these social divisions that was given by the parties within their programmatic offers on social spending. These categories consider only general measures proposed for these groups. To measure all statements that would benefit a particular age group, some of the other 13 categories on welfare programs and beneficiaries must be aggregated.

Graph 7. Parties' emphasis on age groups in Britain (2015).

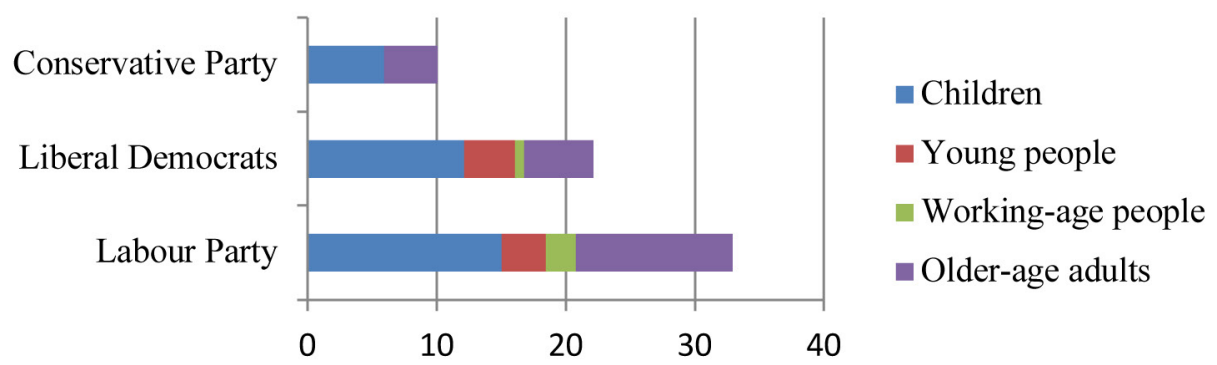

Source: Parties' Social Spending Profiles' dataset, version 2018. The emphasis on the 4 categories on age groups, on the $\mathrm{x}$-axis, measures the importance of these social divisions that was given by the parties within their programmatic offers on social spending. These categories consider only general measures proposed for these groups. To measure all statements that would benefit a particular age group, some of the other 13 categories on welfare programs and beneficiaries must be aggregated. 


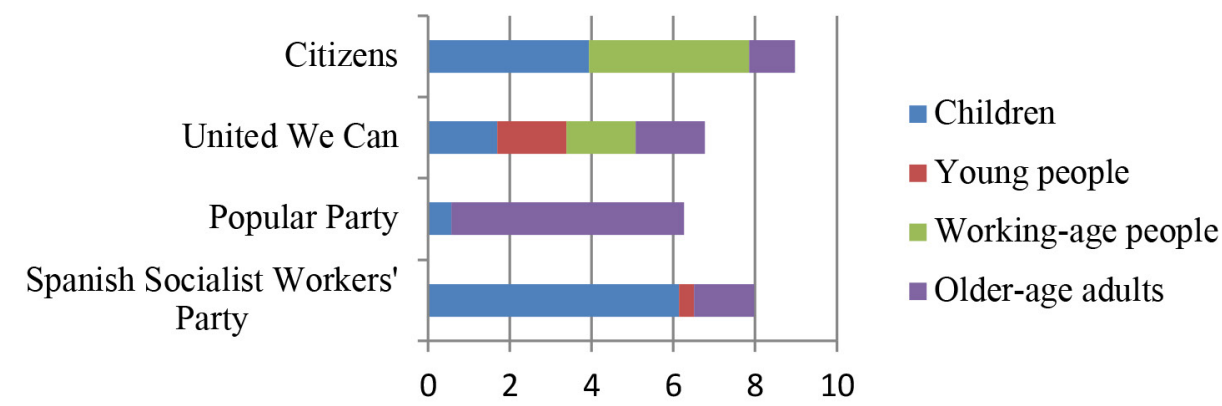

Source: Parties' Social Spending Profiles' dataset, version 2018. The emphasis on the 4 categories on age groups, on the $\mathrm{x}$-axis, measures the importance of these social divisions that was given by the parties within their programmatic offers on social spending. These categories consider only general measures proposed for these groups. To measure all statements that would benefit a particular age group, some of the other 13 categories on welfare programs and beneficiaries must be aggregated.

Graph 9. Parties' emphasis on age groups in France (2017).

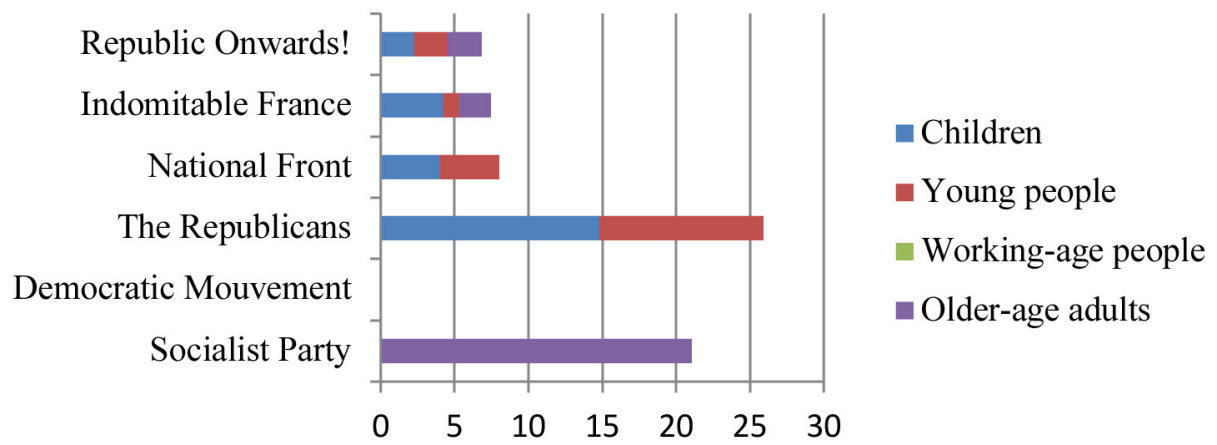

Source: Parties' Social Spending Profiles' dataset, version 2018. The emphasis on the 4 categories on age groups, on the $\mathrm{x}$-axis, measures the importance of these social divisions that was given by the parties within their programmatic offers on social spending. These categories consider only general measures proposed for these groups. To measure all statements that would benefit a particular age group, some of the other 13 categories on welfare programs and beneficiaries must be aggregated.

\subsection{Rationales for social retrenchment}

Variations in the position on social spending barely represent an increase in the number of statements in favor of social cuts or the emphasis on social retrenchment. In the EU-15, only a slight increase in them was evident at the height of the Great Recession. Although they are quantitatively unimportant, analyzing the content of the sentences devoted to social retrenchment is valuable in order to reveal the parties' framings, as the latter may have effects on the allocation of funding.

At the meso level, the percentage of statements in favor of social cuts was very low as compared to the total number of statements on social spending too, except for in the cases of the British Conservative Party (11.74), and the French The Republicans (10) and Republic Onwards! (6.38). See table A2 in the appendix.
Conservative parties in all three countries referred to the negative consequences of social spending with regard to the responsibility of individuals and the cohesion of families and communities; their critiques of social spending were almost all on moral grounds. Liberal parties shared the same framing to a certain extent, but their arguments were more frequently macroeconomic or related to the inefficiency of particular social benefits. See graphs A1 and A2 in the appendix. To conclude with, the Labour Party was the only social democratic party that included statements in favor of social retrenchment in its manifesto.

\section{Conclusions}

This article introduced a procedure to code party manifestos and a 20-item classification to categorize party 
Graph 10. Emphasis on social retrenchment.

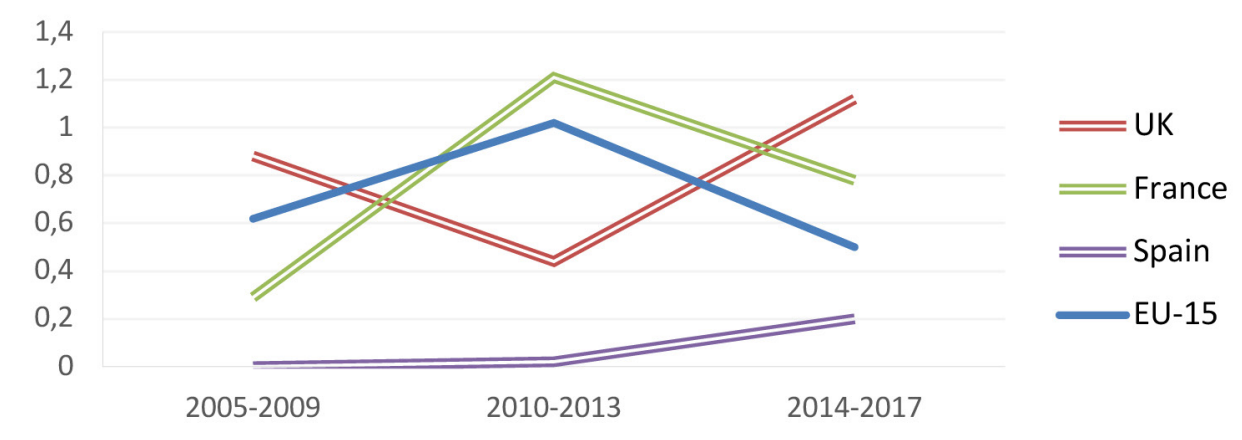

Source: Manifesto Project's dataset, version 2017b. Emphasis on social retrenchment: parties' statements in favor of social cuts $(505+507)$ weighted by the number of seats.

Graph 11. Rationale for social retrenchment.

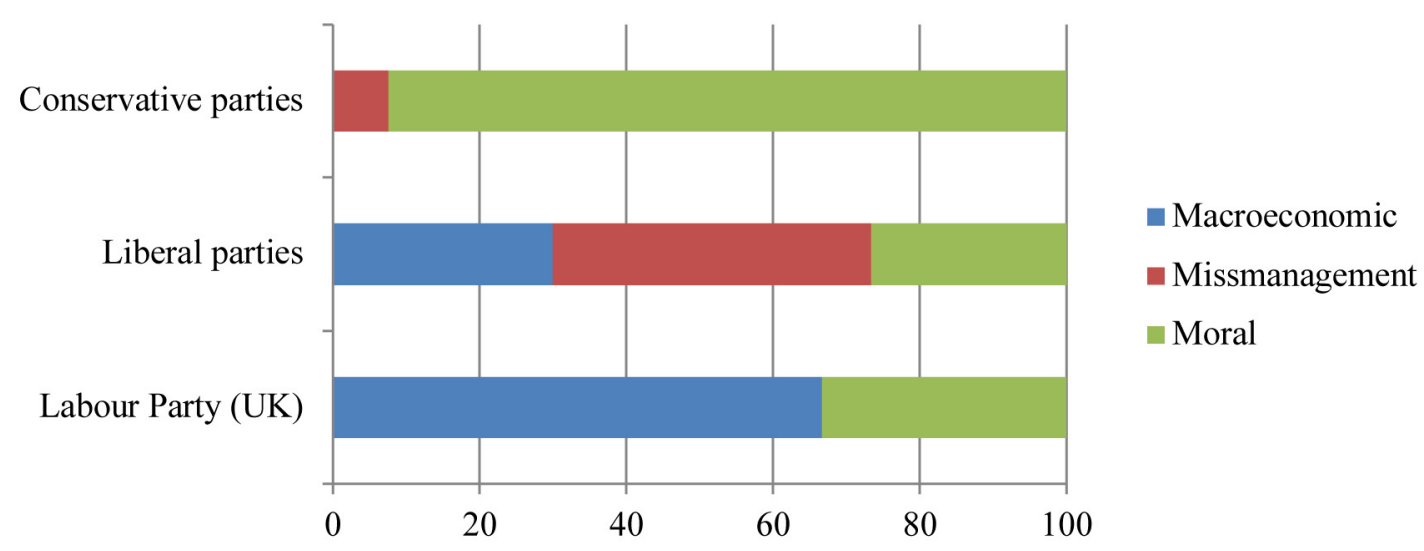

Source: Parties' Social Spending Profiles' dataset, version 2018. The Labour Party is the only social democratic party that included statement in favor of social cuts. The percentages of statements in favor of social retrenchment out of the total number of statements on social spending of the parties represented in this graph are the following: Conservative Party (conservative, UK), 11.74; The Republicans (conservative, France), 10; Popular Party (conservative, Spain), 3.03; Republic Onwards! (liberal, France), 6.38; Liberal Democrats (liberal, UK), 1.75; Labour Party (social democratic, UK), 3.35.

preferences on social spending regarding beneficiaries and programs, especially in terms of their responsiveness to age groups, along with their justification for social retrenchment. The new scheme's rationale is to capture programmatic variation that was previously masked by overall party positions on social spending.

In the 13 parties that were preliminary examined, for instance, it shed light on how conservative and liberal parties hardly paid attention to social programs different from education and health, while social democratic parties made emphasis on social spending on a larger range of welfare programs.

More generally, the study of three general elections [Britain (2015), France (2017) and Spain (2016)] showed that ideologies were linked to parties' preferences regarding the distribution of social spending between programs and the justification for social cuts. Concerning age groups, the results were more blurred, although social democratic parties paid more attention to the new demography.
Parties' preferences on social spending and retrenchment run the gamut between beneficiaries, programs, and rationales; and parties' social priorities and framings evolve. Besides, at the macro level of the party systems, support for social spending across Western Europe continues to be high.

It is worth noting that this now comparable programmatic differentiation on social spending amongst parties and countries is in part caused by factors other than the type of capitalist economy, welfare regime or welfare culture, operating instead at the meso level of the parties and likely also at the micro level of demands.

Therefore, extending this Parties' Social Spending Profiles' dataset to other parties, elections and countries may be helpful to monitor party preferences on social spending and retrenchment, and answer an array of questions on representation within the European Social Model from the early 1990s on. 


\section{Bibliography}

Arts, W and Gelissen, J. (2010). "Models of the Welfare State”, en F. G. Castles, S. Leibfried, J. Lewis, H. Obinger and C. Pierson. The Oxford Handbook of the Welfare State. Oxford: Oxford University Pres, p.p. 569-583.

Beramendi, P., Häusermann, S., Kitschelt, H and Kriesi, H. (2015). "Introduction: The politics of advanced capitalism", en P. Beramendi, S. Häusermann, H. Kitschelt and H. Kriesi. The politics of advanced capitalism. New York: Cambridge University Press, pp. 1-64.

Briggs, A. (2000). "The welfare state in historical perspective", en C. Pierson and F. G. Castles. The Welfare State reader. Cambridge: Polity Press, pp. 18-31.

Bristow, J. (2015). Baby boomers and generational conflict. Basingstoke: Palgrave.https://doi.org/10.1057/9781137454737

Burgoon, B. (2006). Globalization is what parties make of it: Welfare and protectionism in party platforms. Garnet Working Paper. Coventry.

Castles, F. G. and Obinger, H. (2008). "Worlds, families, regimes: Country clusters in European and OECD area public policy", Western European Politics, 31 (1/2): 321-344.

Costamagna, F. (2013). The European semester in action: Strengthening economic policy coordination while weakening the social dimension? LPF-WEL Working Paper.

Darvas, Z. and Tschekassin, O. (2015). Poor and under pressure: The social impact of europe's fiscal consolidation. Bruegel Policy Contribution. Brussels.

Degryse, C., Jepsen, M and Pochet, P. (2013). The Euro Crisis and its impact on national and European social policies. ETUI Working Papers. Brussels.

De la Porte, C. and Heins, E. (2015). "A new era of European integration? Governance of labour market and social policy since sovereign debt crisis", Comparative European Politics, 13 (1): 8-28.

De la Porte, C. and Pochet, P. (2012). "Why and how (still) study the open method of coordination", Journal of European Social Policy, 22 (3): 336-349.

Ebbinghaus, B. (2012). Comparing Welfare State regimes: Are typologies an ideal or realistic strategy?. Draft paper presented at European Social Policy Analysis Network (ESPAnet Conference), September 6-8, Edinburgh, UK.

Ebbinghaus, B. and Manow, P. (2001). Comparing welfare capitalism: Social policy and political economy in Europe, Japan and the USA. London: Routledge.

Esping-Andersen, G. (1990). The three worlds of welfare capitalism. Cambridge: Polity Press, and Princeton: Princeton University Press.

Esping-Andersen, G. (1999). Social foundations of postindustrial economies. Oxford: Oxford University Press.

Esping-Andersen, G. (2002). "A child-centred social investment strategy”, in G. Esping-Andersen, D. Gallie, A. Hemerijck and J. Myles. Why we need a new Welfare State? Oxford, Oxford University Press, pp. 26-67.

Esping-Andersen, G. (2009). The incomplete revolution. adapting to women's new roles. Cambridge: Polity Press.

Esping-Andersen, G. (2015). "The Return of the Family", in P. Beramendi, S. Häusermann, H. Kitschelt and H. Kriesi. The Politics of Advanced Capitalism. New York: Cambridge University Press, pp. 157-176.

Ferragina, E., Seeleib-Kaiser, M and Spreckelsen, T. (2015). "The four worlds of 'Welfare reality'-social risks and outcomes in Europe", Social Policy \& Society, 14 (2): 287-307.

Ferrera, M. (1996). "The 'Southern model' of Welfare on Social Europe”, Journal of European Social Policy, 6 (1): 17-37.

Goerres, A. (2009). The political participation of older people in Europe. The greying of our democracies. Basingstoke: Palgrave.

Hall, P. A. and Soskice, D. (2001). Varieties of capitalism: The institutional foundations of comparative advantage. New York: Oxford University Press.

Häusermann, S. (2010). The politics of Welfare State reform in Continental Europe. New York: Cambridge University Press.

Horn, A., Kevins, A., Jensen, C and Van Kersbergen, K. (2017). "Peeping at the corpus. What is really going on behind the equality and welfare items of the Manifesto Project?". Journal of European Social Policy, 27 (5): 403-416.

Horn, A. and van Kersbergen, K. (2015). Peeping at the Corpus. What is really going on behind the equality and welfare items of the Manifesto Project?. Paper presented at the Manifesto project user conference, 4-5 June, Berlin.

Huber, E. and Stephens, J. D. (2015). "Postindustrial Social Policy", in Beramendi, S. Häusermann, H. Kitschelt and H. Kriesi. The Politics of Advanced Capitalism. New York: Cambridge University Press, pp. 259-281

Kohli, M. (2015). "Generations in Aging Societies: Inequalities, Cleavages, Conflicts", in C. Torp. Challenges of Aging. Pensions, Retirement and Generational Justice. Basingstoke: Palgrave, pp. 265-288.

Leibfried, S. (1992). "Towards a European Welfare State? On Integrating Poverty Regimes into the European Community”, en Z. Ferge and J. E. Kolberg. Social Policy in a Changing Europe. Frankfurt: Campus, pp. 245-279.

Lynch, J. (2006). Age in the Welfare State. The origins of social spending on pensioners, workers, and children. Cambridge: Cambridge University Press.

Lynch, J. (2015). “Age Politics and Pension Systems Development and Reform”, C. Torp. Challenges of aging. Pensions, retirement and generational justice. Basingstoke: Palgrave, pp. 49-60.

Merz, N., Regel, S and Lewandowski, J. (2016). "The Manifesto Corpus. A new resource for research on political parties and quantitative text analysis". Research \& Politics, 26/04, S. 1-8.

Moreno, L. (2016). "Post-crisis and the Bronze Age of Welfare in Europe", in S. Segado Sánchez-Cabezudo and A. López Peláez. P The ailing Welfare State, edited by Madrid: Thomson Reuters Aranzadi, pp. 51-74.

Natali, D. (2009). “The open method of coordination on pensions: Does it de-politicise pensions policy?", West European Politics, 32(4): 810-828.

Pfau-Effinger, B. (2005). "Culture and Welfare State Policies: Reflections on a Complex Interrelation", Journal of Social Policy, 34(1): 3-20.

Vaughan-Whitehead, D. (2015). The European social model in crisis. Is europe losing its soul?. Cheltenham: Edward Elgar.

Volkens, A., Lehmann, P., Matthieß, T., Merz, N., Regel, S and Weßels, B. (2017). The Manifesto data collection. Manifesto Project (MRG/CMP/MARPOR). Version 2017b, WZB Berlin Social Science Center. 


\section{Appendix}

Table A1. Position on social spending on the macro level of party systems and the meso level of the main state-wide parties, in France (2017), Spain (2016) and the UK (2015).

\begin{tabular}{|l|l|l|c|}
\hline \multirow{2}{*}{ Country } & \multicolumn{1}{|c|}{ Parties } & \multicolumn{1}{c|}{ Political family } & Position \\
\hline \multirow{5}{*}{ France } & Socialist Party & Social democratic & 25.01 \\
\cline { 2 - 4 } & Republic Onwards! & Liberal & 11.33 \\
\cline { 2 - 4 } & Democratic Mouvement & Conservative & 18.59 \\
\cline { 2 - 4 } & The Republicans & Conservative & 9.34 \\
\cline { 2 - 4 } & Indomitable France & Left & 9.26 \\
\cline { 2 - 4 } & National Front & Nationalist & 9.69 \\
\hline \multirow{5}{*}{ Spain } & Spanish Socialist Workers' Party & Social democratic & 17 \\
\cline { 2 - 4 } & Citizens & Liberal & 21,45 \\
\cline { 2 - 4 } & Popular Party & Conservative & 14,35 \\
\cline { 2 - 4 } & United We Can & Left & 17,16 \\
\hline \multirow{5}{*}{ UK } & Labour Party & Social democratic & 16.55 \\
\cline { 2 - 4 } & Liberal Democrats & Liberal & 14.3 \\
\cline { 2 - 4 } & Conservative Party & Conservative & 12.15 \\
\hline
\end{tabular}

Source: Manifesto Project's dataset, version 2017b. On the meso level, party position on social spending: $(504+506)-(505+507)$, in a theoretical range between +100 and -100 . On the macro level, these parliamentary party positions weighted by the number of seats.

Table A2. Percentages of statements in favor of social cuts out of the total number of statements on social spending.

\begin{tabular}{|l|l|l|c|}
\hline \multicolumn{1}{|c|}{ Country } & \multicolumn{1}{|c|}{ Parties } & \multicolumn{1}{c|}{$\begin{array}{c}\text { Pocitical family } \\
\text { on social spending (\%) }\end{array}$} \\
\hline France & Socialist Party & Social democratic & 0 \\
\hline & Republic Onwards! & Liberal & 6.38 \\
\hline & Democratic Mouvement & Conservative & 0 \\
\hline & The Republicans & Conservative & 0 \\
\hline & Indomitable France & Left & 0 \\
\hline Spain & National Front & Nationalist & 0 \\
\hline & Spanish Socialist Workers' Party & Social democratic & 0 \\
\hline & Citizens & Liberal & 3.03 \\
\hline & Popular Party & Conservative & 0 \\
\hline UK & United We Can & Left & 3.35 \\
\hline & Labour Party & Social democratic & 1.75 \\
\hline & Liberal Democrats & Liberal & 11.74 \\
\hline
\end{tabular}

Source: Parties' Social Spending Profiles' dataset, version 2018. 
Graph A1. Conservative parties' rationale for social retrenchment.

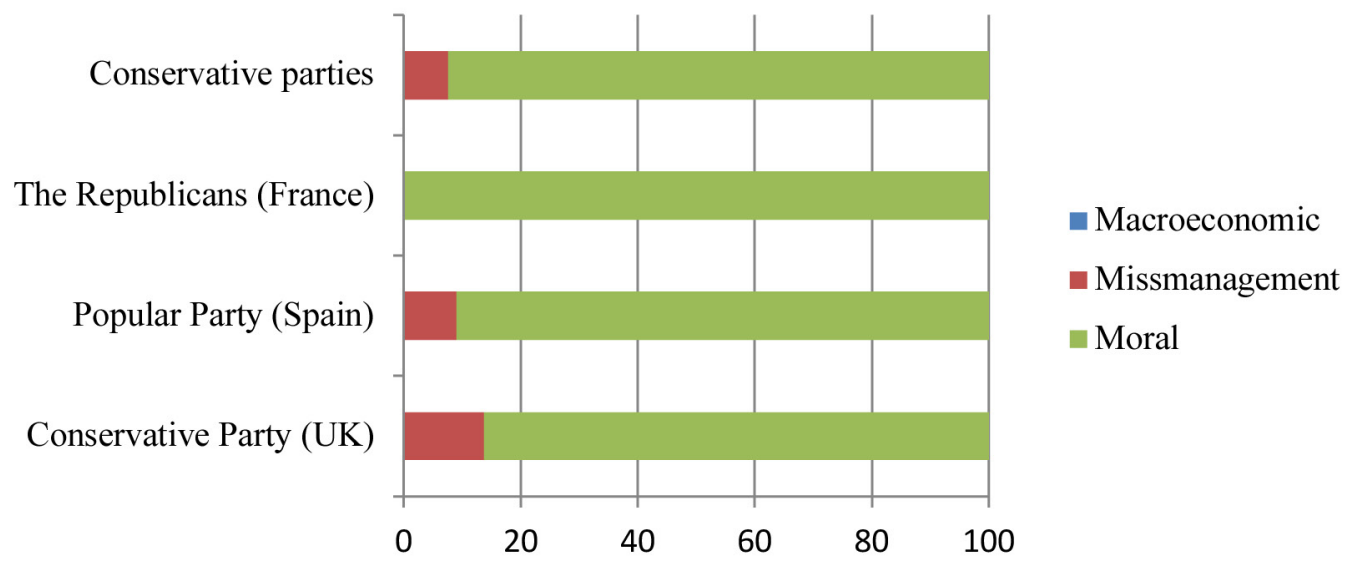

Source: Parties' Social Spending Profiles' dataset, version 2018.

Graph A2. Liberal parties' rationale for social retrenchment.

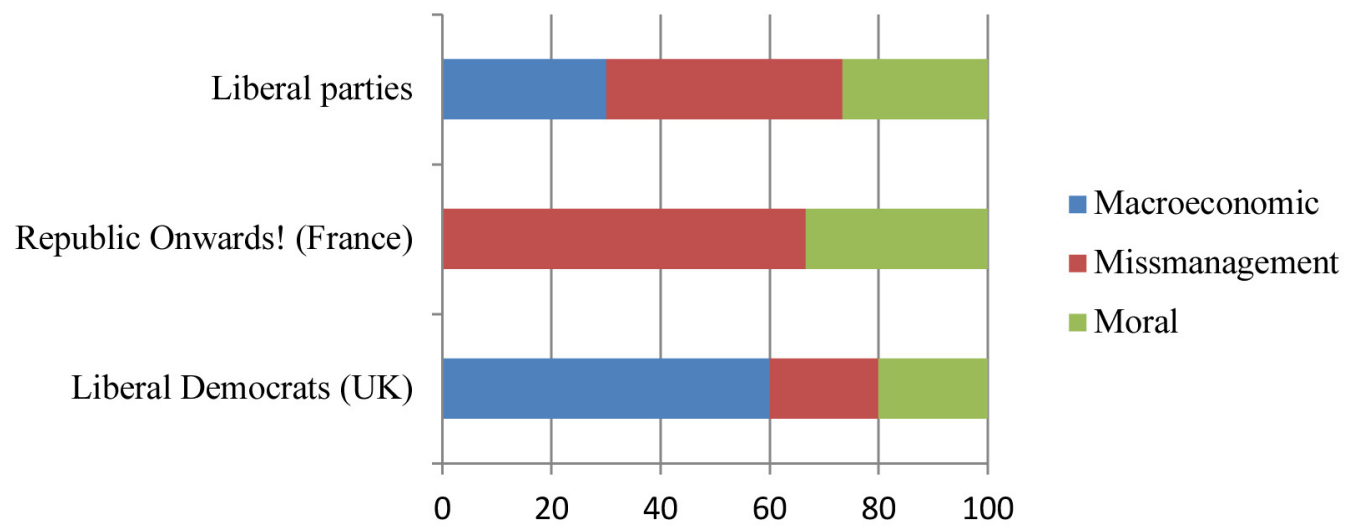

Source: Parties' Social Spending Profiles' dataset, version 2018. 